\title{
Fabrication and Characterisation of Titanium Dioxide Based Dye Sensitized Solar Cell using Flame of the Forest Dye
}

\author{
Baba Alfa (Corresponding Author) \\ Department of Physics, Ibrahim Badamasi Babangida University \\ P.M.B. 11, Lapai, Nigeria \\ Tel: 234-803-451-1406_E-mail:alfaba2003@yahoo.com \\ Matthew Tersoo Tsepav \\ Department of Physics, Ibrahim Badamasi Babangida University \\ P.M.B. 11, Lapai, Nigeria \\ Tel: 234-803-093-9122Ｅ-mail:tsematoo@yahoo.com \\ Raymond Limen Njinga \\ Department of Physics, Ibrahim Badamasi Babangida University \\ P.M.B. 11, Lapai, Nigeria \\ Tel: 234-706-823-4006_E-mail: njingaraymond@yahoo.co.uk \\ Ibrahim Abdulrauf \\ Department of Physics, Ibrahim Badamasi Babangida University \\ P.M.B. 11, Lapai, Nigeria \\ Tel: 234-803-572-6666_E-mail: ibrauf@yahoo.com
}

Received: October 8, 2011

doi:10.5539/apr.v4n1p48
Accepted: November 7, $2011 \quad$ Published: February 1, 2012

URL: http://dx.doi.org/10.5539/apr.v4n1p48

\begin{abstract}
A Titanium dioxide $\left(\mathrm{TiO}_{2}\right.$ ) based Die Sensitised Solar Cell (DSSC) using Flame of the Forest (Butea monosperma) was fabricated on a glass substrate and characterized with scanning electron microscopy (SEM). The cell had $\mathrm{TiO}_{2}$ as a photo electrode, flame of forest as a dye sensitizer, iodide/iodide solution as an electrolyte and Platinum/Transparent Conducting Oxide as a counter electrode. The photo electrochemical characteristics of TiO DSSCs were tested under simulated sunlight AM 1.5 from a solar simulator with the radiant power of $100 \mathrm{~mW} / \mathrm{cm}^{2}$. It was found that the DSSC based on $\mathrm{TiO}_{2}$ generated photocurrent with short-circuit current, $\mathrm{I}_{\mathrm{sc}}=$ $0.14 \mathrm{~mA}$; open-circuit voltage, $\mathrm{V}_{\mathrm{oc}}=0.5$; fill factor, $\mathrm{ff}=0.652$ and a photo conversion efficiency of $0.08 \%$. This is comparatively good when evaluated with similar low-cost DSSCs. The Isc was found to increase with increasing thickness of the $\mathrm{TiO}_{2}$ photo electrode, while the $\mathrm{V}_{\text {oc }}$ of $\mathrm{TiO}_{2} \mathrm{DSSC}$ was found to be independent of the morphology and dye adsorption surface area of $\mathrm{TiO}_{2}$.
\end{abstract}

Keywords: Fabrication, Solar Cell, Butea monosperma, Titanium dioxide

\section{Introduction}

Electric power has now become the fundamental platform that supports most of our physical needs. However, population growth, industrialization, gradual spread of the modern style of living, etc have contributed immensely to the increased demand for electricity and the need for improved supply has become imperative. Several technologies using different means have been used to generate this power. Among them are: fossil fuel (oil, coal and natural gas), nuclear, hydroelectric, wind, geothermal, biomass and solar photovoltaic sources. Some of these energy sources present technical and environmental challenges. 
Fossil fuel technology can be categorized as a non-renewable technology and once exhausted power sources from them will go to extinction. Oil for instance, is used a million times faster than it is formed, and most experts agree that a complete depletion is imminently unavoidable. As at today, a reasonable percentage of the power generated is from fossil fuels. These fuels emit a lot of gases such as Sulfur dioxide and nitrous oxide (main causes of acid rains and smog) that pollute the environment and contribute to global warming and climate change.

Solar or photovoltaic (PV) power is an attractive alternative as its installations can be designed on a small scale, point-of-use basis with little environmental hazards, readily available materials, low land requirement and maintenance cost. They do not require mechanically moving parts, and are therefore potentially robust and reliable. The output compares favourably with other energy sources.

Photovoltaic technology is the process of converting solar energy into usable electric power. A typical photovoltaic cell is an integrated device consisting of layers of semiconductor materials and electric contacts. Several of such cells are usually interconnected to form an integrated assembly that is called a solar cell module. Such modules are then placed at the appropriate places where they get exposed to bright sunlight to enable them store more charges and convert the energy from sunlight into electricity by the photovoltaic effect.

The Dye-Sensitized Solar Cells (DSSCs) are relatively new class of low-cost solar cells that belong to the group of thin film solar cells. They are very promising because they are made from low-cost materials and do not need elaborate apparatus for their manufacture. They are currently the most efficient third-generation solar technologies available (Basic Research Solar Energy Utilization 16, 2005).

Though Plausible, one major disadvantage in the DSSC design is the use of the liquid electrolyte, which has temperature stability problems. At low temperatures the electrolyte can freeze, ending power production and potentially leading to physical damage. (Science Daily, 2008). Higher temperatures cause the liquid to expand, making sealing of the panels a serious problem. The electrolyte solution also contains volatile organic solvents and must be carefully sealed. These, along with the fact that the solvents permeate plastics, has precluded large-scale outdoor application and integration into flexible structure (Science Daily, 2008). Replacing the liquid electrolyte with a solid has been a major ongoing interest for research. Recent experiments using solidified melted salts have shown some promise but currently suffer from higher degradation during continued operation and are not flexible (Nathalie, 2006). Despite these, their price-performance ratio is high enough to allow them to compete with fossil fuels in electricity generation.

\section{Theory, Materials and Methodology}

\subsection{Theory}

In the conventional solar cell, for instance, silicon solar cell, silicon acts as both the source of photoelectrons as well as electric field to separate the charges and create a current. In the dye-sensitized solar cell however, the bulk of the semiconductor is used solely for charge transport while the photoelectrons are provided from a separate photosensitive dye. Charge separation occurs at the surfaces between the dye, semiconductor and electrolyte. The cell comprises of a transparent conducting glass electrode coated with porous nanocrystalline titanium dioxide $\left(\mathrm{nc}-\mathrm{TiO}_{2}\right)$ dye molecules. Attached to the surface of the $\mathrm{nc}^{-\mathrm{TiO}_{2}}$ is an electrolyte containing a reduction-oxidation couple such as $\mathrm{I}^{-} / \mathrm{I}_{3}^{-}$and a catalyst coated counter-electrode (figure 1). At illumination, the cell produces voltage over and current through an external load connected to the electrodes. (Grätzel \& Kay, 1996).

The incoming photon is absorbed by the dye molecule adsorbed on the surface on the nanocrystalline $\mathrm{TiO}_{2}$ particle and an electron from a molecular ground state $S^{0}$ is excited to a higher excited state $S^{*}$ (eqn.1). The exited electron is ejected to the conduction band of the $\mathrm{TiO}_{2}$ particle leaving the dye molecule to an oxidized state $\mathrm{S}^{+}$(eqn. 2). The ejected electron percolates through the porous nanocrystalline structure to the transparent conducting oxide layer of the glass substrate (anode) and finally through an external load to the counter-electrode (cathode) (eqn. 3). At the counter-electrode the electron is transferred to triiodide in the electrolyte to yield iodine (eqn. 4), and the cycle is closed by reduction of the oxidized dye by the iodine in the electrolyte (eqn. 3). This operating cycle according to Hagfeldt and Grätzel (1995) and Mathews (1996) can be summarized in the redox reaction equations (1) to (4).

Anode: 


$\begin{array}{cccc}\mathrm{S} & \stackrel{h v}{\rightarrow} & \mathrm{S}^{*} & \text { Absorption } \\ \mathrm{S}^{*} & & \mathrm{~S}^{+}+3 \mathrm{e}^{-} & \text {Electron ejection } \\ \mathrm{S}^{+}+3 \mathrm{I} & & \mathrm{S}+\mathrm{I}_{3}^{-} & \rightarrow\end{array}$

Cathode:

$$
\mathrm{I}_{3}^{-}+3 \mathrm{e}^{-} \rightarrow \quad 3 \mathrm{I} \quad \text { Regeneration }
$$

The maximum theoretical value for the photovoltage at open circuit condition is determined by the potential difference between the conduction band edge of the $\mathrm{TiO}_{2}$ and the redox potential of the $\mathrm{I}^{-} / \mathrm{I}_{3}$ - pair in the electrolyte (Cahen, 2000). The operation of the cell is regenerative since no chemical substances are neither consumed nor produced during the working cycle, as visualized in the cell reactions shown in figure 2.

The process of DSSC fabrication involves injecting an electron directly into the $\mathrm{TiO}_{2}$ but this does not introduce a hole in the $\mathrm{TiO}_{2}$, but an extra electron. Though it is energetically possible for the electron to recombine into the dye, the rate at which this occurs is quite slow compared to that at which the dye regains an electron from the surrounding electrolyte. Recombination directly from the $\mathrm{TiO}_{2}$ to species in the electrolyte is also possible although, again, for optimized devices this reaction is rather slow (Jessica, 2003). On the contrary, electron transfer from the platinum coated electrode to species in the electrolyte is unnecessarily very fast. As a result of these favorable differential kinetics, DSSCs work even in low-light conditions, whereas traditional designs would suffer a cutout at some lower limit of illumination when charge carrier mobility is low and recombination becomes a major issue. The cutoff is so low that they are even being proposed for indoor use where they collect energy from small lights from devices in the house (Kimberly, 2006).

\subsubsection{I-V Characteristics of a DSSC}

Generation of electrical power under illumination is achieved by the capability of the photovoltaic device to produce voltage over an external load and current through the load at the same time. This is characterized by the current-voltage (IV) curve of the cell at certain illumination and temperature.

When the cell is short circuited under illumination, the maximum (short circuit) current, $\mathrm{I}_{\mathrm{SC}}$ is generated, while under open circuit conditions no current can flow and the voltage (open circuit voltage, $\mathrm{V}_{\mathrm{OC}}$ ) is at its maximum.

The point in the IV-curve yielding maximum power is called the maximum power point (MPP). The fill factor (ff) is another parameter in the characterization of DSSC. It is defined as:

$$
\mathrm{ff}=\frac{V_{m p p \cdot I_{m p p}}}{V_{o c} \cdot I_{s c}}
$$

where:

$\mathrm{I}_{\mathrm{MPP}}=$ the current at the maximum power output

$\mathrm{V}_{\mathrm{MPP}}=$ the voltage at the maximum power output

$I_{\mathrm{sc}}=$ the short-circuit current

$\mathrm{V}_{\mathrm{oc}}=$ the open-circuit voltage

The Maximum Power Output,

That is

$$
\mathrm{P}_{\mathrm{max}}=\mathrm{V}_{\mathrm{mpp}} \cdot \mathrm{I}_{\mathrm{mpp}}
$$

$$
P_{\text {max }}=V_{o c} \cdot I_{s c} \cdot f f .
$$

While the physical principles behind the operation of different types of photovoltaic cells are generally different, the current-voltage curve of well performing cells are similar, and can be characterized and compared with each other in terms of ff, $\mathrm{V}_{\mathrm{OC}}$, and $\mathrm{I}_{\mathrm{SC}}$.

\subsubsection{Cell Efficiency}

The energy conversion efficiency of the solar cell $(\eta)$ is defined as the ratio of the power produced by the cell $\left(\mathrm{P}_{\max }\right)$ to the power incident on the representative area of the cell $\left(\mathrm{P}_{\text {light }}\right)$

That is: 


$$
\eta=\frac{P_{\max }}{P_{\text {light }}}
$$

The efficiency of the solar cell depends on the temperature of the cell, which in turn depends on the quality of the illumination, i.e. the total light intensity and the spectral distribution of the intensity. For this reason, a standard measurement condition has been developed to facilitate comparable testing of solar cells, between different laboratories. In the standard condition, the light intensity is $1000 \mathrm{~W} / \mathrm{m}^{2}$, the spectral distribution of the light source is that of AM1.5 global standard solar spectrum and the temperature of the cell is $25^{\circ} \mathrm{C}$ (Halme, 2002). The power output of the solar cell at these conditions is the nominal power of the cell, or module, and is reported in peak watts, Wp. In practice, special solar simulator light sources are used for the standard measurements (Halme, 2002).

\subsection{Materials and Methodology}

For a DSSC to be useful for practical applications, the device should be able to efficiently convert solar energy into electricity, the materials used need to be nontoxic and the device production method environmentally friendly. The following components were purchased from Solaronix SA, Switzerland and used as received:

i. The conductive glass TCO 30-8, 3mm thick sodalime glass coated with electrically conducting fluorine doped tin oxide (FTO) layer with surface resistivity of $15 \mathrm{ohm} / \mathrm{sq}$.

ii. Screen-printable $\mathrm{TiO}_{2}$ paste (anatase) Ti-Nanoxide D/SP

iii. Electrolyte (iodolyte) AN-50

iv. Sealing gasket SX1170-25PF of $25 \mu \mathrm{m}$ thickness

v. Screen-printable platinum catalyst, Pt-catalyst T/SP

In addition, locally extracted dye from flame of the forest (Butea monosperma) was used. The Butea monosperma flower was carefully cut and 20 grams was weighed out, crushed with a porcelain mortar and pestle ant then filtered to extract the dye which served as the sensitizer for the cell.

To prepare the working electrodes, the fluorine-doped tin oxide (FTO) glass ( $3 \mathrm{~mm}$ thick sodalime coated with an electronically conducting layer with a surface resistivity of $15 \mathrm{ohm} / \mathrm{sq}$ ) used as current collector was first cleaned in a detergent solution then rinsed with water and ethanol and blown dry. A layer of nanocrystalline- $\mathrm{TiO}_{2}$ paste was then screen-printed onto the FTO glass substrate using a polyester mesh of 90 and kept in a clean Petri dish for 3 minutes so that the paste could settle to reduce the irregularity of the surface and then dried for 6 minutes at about $125^{\circ} \mathrm{C}$ in open air. This screen-printing procedure with the paste (coating, storing and drying) was repeated to obtain a working electrode of appropriate thickness of $9 \mu \mathrm{m}$.

The device was then taken through a sintering process to allow the titanium dioxide $\left(\mathrm{TiO}_{2}\right)$ nanocrystals to melt partially together, in order to ensure electrical contact and mechanical adhesion on the glass. The electrodes coated with the $\mathrm{TiO}_{2}$ pastes were then gradually heated under an air flow at $150^{\circ} \mathrm{C}$ for 2 minutes, at $200^{\circ} \mathrm{C}$ for 2 minutes, at $250^{\circ} \mathrm{C}$ for 2 minutes, at $300^{\circ} \mathrm{C}$ for 2 minutes, at $350^{\circ} \mathrm{C}$ for 2 minutes, at $400^{\circ} \mathrm{C}$ for 2 minutes, at $450^{\circ} \mathrm{C}$ for 2 minutes and finally at $500^{\circ} \mathrm{C}$ for 30 minutes to increase the adhesion of the $\mathrm{TiO}_{2}$ on the glass substrate. While heating up the electrode, it first turned brownish and later yellowish-white due to the temperature dependent band-gap narrowing in the pure titanium dioxide (anatase) indicating that the sintering process was completed and the cooling rate was made gradual to avoid cracking of the glass.

After cooling, the $\mathrm{TiO}_{2}$ electrode was immersed in the dye (extracted from the Flame of the forest) and kept at room temperature for 19 hours to complete the sensitizer uptake. The photo electrode and counter electrode were then assembled into a sandwich-type cell and sealed with a hot-melt sealing gasket of $25 \mu \mathrm{m}$ thickness made from the ionomer Surlyn, SX1170-25PF, cut out gaskets or strips forming the sealing frame to be deposited on top of one of the glass electrodes. A drop of the electrolyte was then put on and sealed using amosil sealant.

In order to have good electrical contact between the connections and the photovoltaic measurement equipment, a strip of wire was attached and sealed with amosil sealant to the edge of the FTO outside of the cell which was applied on each side of the FTO electrodes. Figures 3 and 4 show a Cross-section of assembled dye solar cell showing sealing rim and a typical assembled cell respectively.

\section{Results and Discussion}

The Energy-Dispersive X-ray Fluorescence Analysis (EDXRF) was used for the spectrochemical determination of elemental composistion of $\mathrm{TiO}_{2}$ compound which was carried out at Sheda Science and Technology Complex (SHESTCO), Abuja. The analysis of the sample (figure 5) showed the presence of three elements: Titanium (Ti), 
Oxygen $(\mathrm{O})$ and Nitrogen $(\mathrm{N})$. $\mathrm{TiO}_{2}$ resulted from the reaction between the first two compounds while the presence of Nitrogen $(\mathrm{N})$ might be attributed to the processes of blowing the wet $\mathrm{TiO}_{2}$ by hand-dryer in the open air in which Nitrogen accounts for $\mathrm{Ca}-78 \%$ of its composition.

The electrical characterization parameters of the solar cell (DSSC) were determined through a solar simulator, Model 4200-SCS Semiconductor Characterization System under the irradiation of AM $1.5\left(100 \mathrm{mWcm}^{-2}\right)$.

\subsection{I-V Characteristics of the fabricated DSSC}

The I-V characteristic of the fabricated cell is shown in figure 6.

The area A of the designed cell was $1.4 \mathrm{~cm} \times 0.4 \mathrm{~cm}=0.56 \mathrm{~cm}^{2}$

From the figure, the value of the current density $\mathrm{J}=0.25 \mathrm{~mA} / \mathrm{cm}^{2}$ at $\mathrm{V}_{\text {oc }}=0$.

Similarly, the open circuit voltage $\mathrm{V}_{\mathrm{oc}}=0.5 \mathrm{~V}$ at current $\mathrm{J}=0$.

From I = J.A

$I_{\mathrm{sc}}=0.25 \times 10^{-3} \mathrm{~mA} / \mathrm{cm}^{2} \times 0.56 \mathrm{~cm}^{2}$

So that $\mathrm{I}_{\mathrm{sc}}=0.14 \mathrm{~mA}$

and $\mathrm{I}_{\mathrm{sc}} \cdot \mathrm{V}_{\mathrm{oc}}=0.14 \mathrm{~mA} \times 0.5 \mathrm{~V}=7.0 \times 10^{-5} \mathrm{AV}$

From the results in table 1:

$\mathrm{I}_{\max }=0.000140854, \mathrm{~V}_{\max }=0.323965$

which gives:

$\mathrm{P}_{\max }=4.563176611 \times 10^{-5}$

The Fill factor

$$
(\mathrm{ff})=\frac{V_{\max } \cdot I_{\max }}{V_{o c} \cdot I_{s c}}=\frac{4.563176611 \times 10^{-5}}{7.0 \times 10^{-5}}=0.652
$$

Efficiency,

$$
\eta=\frac{P_{\max }}{P_{\text {in }}}
$$

With

$$
\begin{gathered}
P_{\text {in }}=100 \mathrm{mWcm}^{-2} \times 0.56 \mathrm{~cm}^{2}=56 \mathrm{~mW}, \\
\eta=\frac{4.563176611 \times 10^{-5}}{56 \times 10^{-3}}=0.08 \%
\end{gathered}
$$

With this efficiency, the performance of the fabricated cell is reasonably good when compared with the cells of other laboratory synthesized dyes of some other natural dyes. For instance, Bello (2011) used sobo dye, an extract from sobo flower plant to get an efficiency of $0.035 \%$. (Ednan et al., 2007) used a synthetic dye (more expensive than the natural dye) and $\mathrm{TiO}_{2}$ electrode and had an efficiency of $0.15 \%$.

Although this efficiency may appear to be low for any practical application, the cell performance is comparable to similar low-cost DSSC technology available today. Recent proposition for DSSC that incorporates a barrier such as $\mathrm{ZnO}, \mathrm{MgO}$ as shell between the dye and the $\mathrm{TiO}_{2}$ layer may greatly increase the efficiency of the cell as the core-shell technology reduces recombination of electron and oxidized dye molecule (Matthew, 1996).

\section{Conclusion and Recommendations}

The dye-sensitized nanocrystalline electrochemical photovoltaic system has become a validated and credible competitor to solid-state junction devices for the conversion of solar energy into electricity. The recent developments in the area of sensitizers for these devices have led to dyes which absorb across the visible spectrum leading to higher efficiencies.

This work provides the first practical example of DSSC devices made with locally extracted dye from Flame of the forest as a photo sensitizer which gave an efficiency of $0.08 \%$. When compared with a typical DSSC based on laboratory synthesized dyes, the power conversion efficiency of the DSSC is good as the extent of diffusion of electrons to the conduction band of $\mathrm{TiO}_{2}$ (i.e. electron injection from the dye to $\mathrm{TiO}_{2}$ ) was normal due to the good absorption of light by the dye. 
Even though the efficiency of the solar cell is relatively good when manufactured in the simple laboratory conditions, we believe that significant improvement of the cell efficiency can be achieved by means of more careful cell preparation and evaluation of the used dye and/or other sources of dyes in our immediate environment. More attention is perhaps needed to exclude any unwanted substances and dust particles during the preparation. It is apparent also that a more systematic approach to the dye cell preparation be used in future. In addition, antioxidants should also be used to protect and improve the efficiency of the cell.

The new DSSC materials should be considered as interesting future alternatives for the conventional PV materials as incorporation of these materials with existing large scale manufacturing processes could open new directions for the development of low-cost solar cells in the future.

Finally, the work should be continued by investigating dyes from other sources and methods and with a systematic progression to raise the efficiency of the cells.

\section{References}

Basic Research Needs for Solar Energy Utilization. (2005). U.S. Department of Energy, Office of Basic Energy Sciences.

Bello A. (2011). Fabricated dye sensitized solar cell using dye extracted from Sobo as electrolyte. Sheda. A research Paper presented at Sheda Science and Technology Complex, Abuja.

Cahen D. (2000). Nature of Photovoltaic Action in Dye-Sensitized Solar Cells. Journal of Physical Chemistry, volume 104, pp 2053-2059. http://dx.doi.org/10.1021/jp993187t

Ednan J., Raluca S., Marcios S., Paulo R., Jilian R., Elson L., \& Jose A. (2007). Dye sensitized solar cell architecture based on indium-tin oxide nano-wires coated with titanium dioxide. Elsevier, 57, $277-280$.

Grätzel M., \& Kay A. (1996). Low cost photovoltaic modules based on dye sensitized nanocrystalline titanium dioxide and carbon powder. Solar Energy Materials \& Solar Cells, 44, 99-117. http://dx.doi.org/10.1016/0927-0248(96)00063-3

Grätzel M., \& O'Regan B. (1991). A low cost high-efficiency solar cell based on dye-sensitized colloidal TiO2 films. Nature, 353, 24 October, 737-740.

Hagfeldt A., \& Grätzel M. (1995). Light-Induced Redox Reactions in Nanocrystalline Systems. Chemical. Revolution, 95, 49-68.

Halme Janne. (2002). Dye-sensitized nanostructured and organic photovoltaic cells: Technical review and preliminary tests. Photovoltaic Resistance and Application, 8, 1, 141-150.

Jessica Krüger. ( 2003). Interface engineering in solid-state dye sensitized solar cells. École Polytechnique Fédérale de Lausanne.

Kimberly Patch. (2006). Solar cell doubles as battery. Technology Research News.

Matthews, D. (1996). Calculation of the photocurrent-potential characteristic for regenerative, sensitized semiconductor electrodes. Solar Energy Materials and Solar Cells, 44, 119-155.

Nathalie Rossier-Iten. (2006). Solid hybrid dye-sensitized solar cells: New organic materials charge recombination and stability. École Polytechnique Fédérale de Lausanne.

Science Daily. (2008). New Efficiency Benchmark for Dye sensitized Solar Cells. Ecole Polytechnique Fédérale de Lausanne, $3^{\text {rd }}$ November. 
Table1. Voltage, Current Density and Power for I-V Characteristics of the DSSC

\begin{tabular}{|c|c|c|c|}
\hline Voltage in (volts) & Current in $(\mathrm{mA})$ & current density J $\left(\mathrm{mA} / \mathrm{cm}^{2}\right)$ & Power in watt \\
\hline-0.00012 & -0.00018 & 0.000346154 & $-4.15385 \mathrm{E}-08$ \\
\hline 0.011885 & -0.00013 & 0.00025 & $2.97125 \mathrm{E}-06$ \\
\hline 0.023911 & -0.00012 & 0.000230769 & $5.51792 \mathrm{E}-06$ \\
\hline 0.035916 & -0.000114 & 0.000219231 & $7.87389 \mathrm{E}-06$ \\
\hline 0.047921 & -0.00011 & 0.000211538 & $1.01371 \mathrm{E}-05$ \\
\hline 0.059926 & -0.000111 & 0.000213462 & 1.27919E-05 \\
\hline 0.071945 & -0.000107 & 0.000205769 & $1.48041 \mathrm{E}-05$ \\
\hline 0.083954 & -0.000104 & 0.0002 & $1.67908 \mathrm{E}-05$ \\
\hline 0.09596 & -0.000102 & 0.000196154 & $1.88229 \mathrm{E}-05$ \\
\hline 0.107972 & -0.000101 & 0.000194231 & $2.09715 \mathrm{E}-05$ \\
\hline 0.119976 & -0.000113 & 0.000217308 & $2.60717 \mathrm{E}-05$ \\
\hline 0.131979 & -0.000111 & 0.000213462 & $2.81724 \mathrm{E}-05$ \\
\hline 0.143979 & -0.00011 & 0.000211538 & $3.04571 \mathrm{E}-05$ \\
\hline 0.157243 & -0.000105 & 0.000201923 & $3.1751 \mathrm{E}-05$ \\
\hline 0.167963 & $-9.66 \mathrm{E}-05$ & 0.000185762 & $3.12011 \mathrm{E}-05$ \\
\hline 0.179958 & $-9.39 \mathrm{E}-05$ & 0.000180493 & $3.24811 \mathrm{E}-05$ \\
\hline 0.191956 & $-9.24 \mathrm{E}-05$ & 0.000177652 & $3.41013 \mathrm{E}-05$ \\
\hline 0.20394 & $-9.15 E-05$ & 0.00017589 & $3.5871 \mathrm{E}-05$ \\
\hline 0.215924 & $-9.00 \mathrm{E}-05$ & 0.000173138 & $3.73846 \mathrm{E}-05$ \\
\hline 0.227928 & $-8.83 E-05$ & 0.000169771 & $3.86955 \mathrm{E}-05$ \\
\hline 0.239911 & $-8.70 \mathrm{E}-05$ & 0.000167293 & 4.01355E-05 \\
\hline 0.251916 & $-8.51 \mathrm{E}-05$ & 0.000163664 & 4.12297E-05 \\
\hline 0.2639 & $-8.32 \mathrm{E}-05$ & 0.000160056 & 4.22389E-05 \\
\hline 0.275904 & $-8.17 \mathrm{E}-05$ & 0.000157089 & 4.33414E-05 \\
\hline 0.28793 & $-7.93 \mathrm{E}-05$ & 0.000152506 & 4.39112E-05 \\
\hline 0.299935 & $-7.73 \mathrm{E}-05$ & 0.000148724 & 4.46075E-05 \\
\hline 0.31194 & $-7.45 \mathrm{E}-05$ & 0.000143341 & $4.47138 \mathrm{E}-05$ \\
\hline 0.323965 & $-7.32 \mathrm{E}-05$ & 0.000140854 & 4.56317E-05 \\
\hline 0.335968 & $-6.92 \mathrm{E}-05$ & 0.000133107 & $4.47196 \mathrm{E}-05$ \\
\hline 0.347976 & $-6.61 E-05$ & 0.000127138 & $4.42411 \mathrm{E}-05$ \\
\hline 0.359982 & $-6.28 \mathrm{E}-05$ & 0.000120826 & 4.3495E-05 \\
\hline 0.371994 & $-5.95 \mathrm{E}-05$ & 0.000114495 & 4.25913E-05 \\
\hline 0.384001 & $-5.56 \mathrm{E}-05$ & 0.000106926 & $4.10598 \mathrm{E}-05$ \\
\hline 0.39601 & $-4.79 E-05$ & $9.21898 \mathrm{E}-05$ & $3.65081 \mathrm{E}-05$ \\
\hline 0.408004 & $-4.73 E-05$ & $9.088 \mathrm{E}-05$ & $3.70794 \mathrm{E}-05$ \\
\hline 0.419998 & $-4.41 \mathrm{E}-05$ & $8.47401 \mathrm{E}-05$ & $3.55907 \mathrm{E}-05$ \\
\hline 0.431994 & $-3.71 \mathrm{E}-05$ & $7.13013 \mathrm{E}-05$ & 3.08017E-05 \\
\hline 0.44399 & $-2.99 \mathrm{E}-05$ & 5.75309E-05 & $2.55431 \mathrm{E}-05$ \\
\hline 0.45599 & $-2.27 \mathrm{E}-05$ & 4.3617E-05 & $1.98889 \mathrm{E}-05$ \\
\hline 0.467975 & $-1.40 \mathrm{E}-05$ & $2.68518 \mathrm{E}-05$ & $1.2566 \mathrm{E}-05$ \\
\hline 0.479961 & $-1.66 \mathrm{E}-05$ & $3.18585 \mathrm{E}-05$ & $1.52908 \mathrm{E}-05$ \\
\hline 0.491946 & $-3.27 \mathrm{E}-06$ & $6.29338 \mathrm{E}-06$ & $3.096 \mathrm{E}-06$ \\
\hline 0.503951 & $1.01 \mathrm{E}-05$ & $-1.94897 \mathrm{E}-05$ & $-9.82187 E-06$ \\
\hline 0.515955 & $3.32 \mathrm{E}-05$ & $-6.38663 \mathrm{E}-05$ & $-3.29522 \mathrm{E}-05$ \\
\hline 0.52794 & 5.09E-05 & $-9.7846 \mathrm{E}-05$ & $-5.16568 \mathrm{E}-05$ \\
\hline 0.539944 & 7.04E-05 & -0.000135453 & $-7.31373 \mathrm{E}-05$ \\
\hline 0.55195 & $9.15 \mathrm{E}-05$ & -0.000176037 & $-9.71638 \mathrm{E}-05$ \\
\hline
\end{tabular}




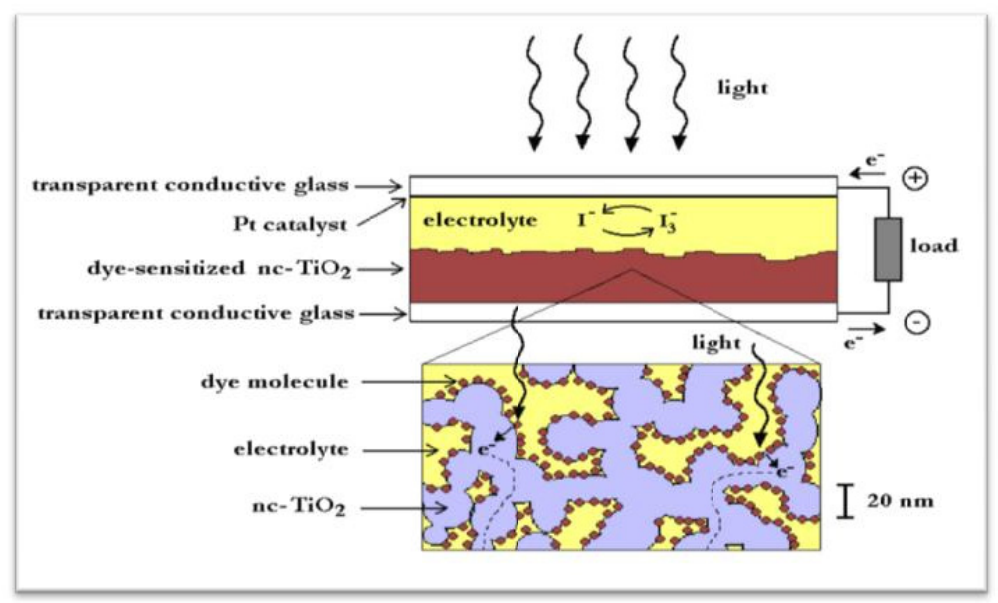

Figure 1. A schematic representation of the structure and components of the dye-sensitized solar cell, (Grätzel and Kay, 1996)

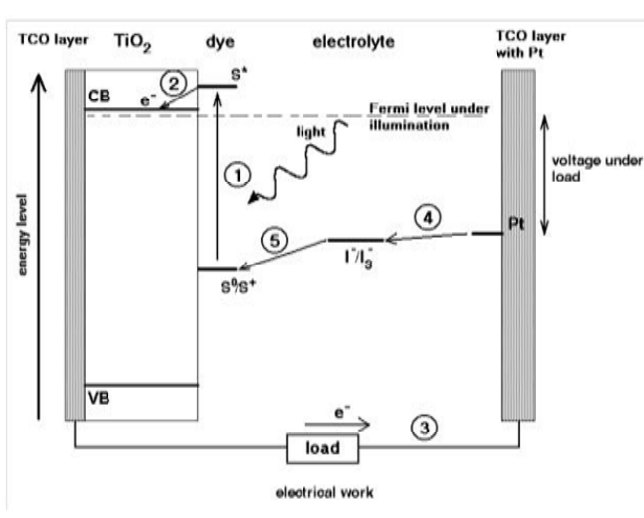

Figure2(a). The working principle of a dye-sensitized nanostructured solar cell. (Grätzel O'Regan, (1991)

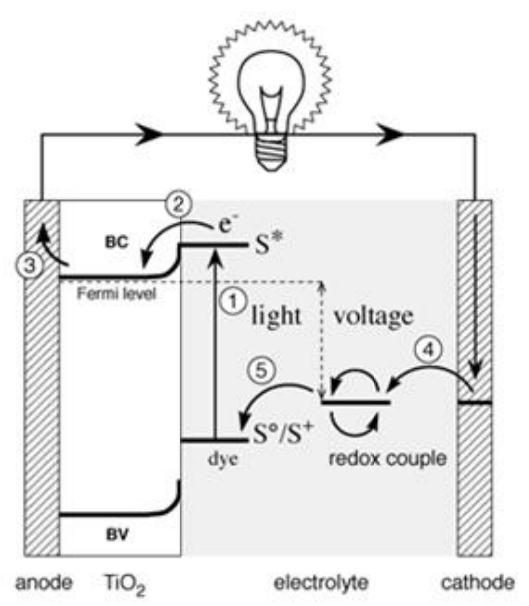

Figure 2b. Schematics of operating principles of a dye-sensitized solar cell.

(Grätzel O'Regan, (1991)

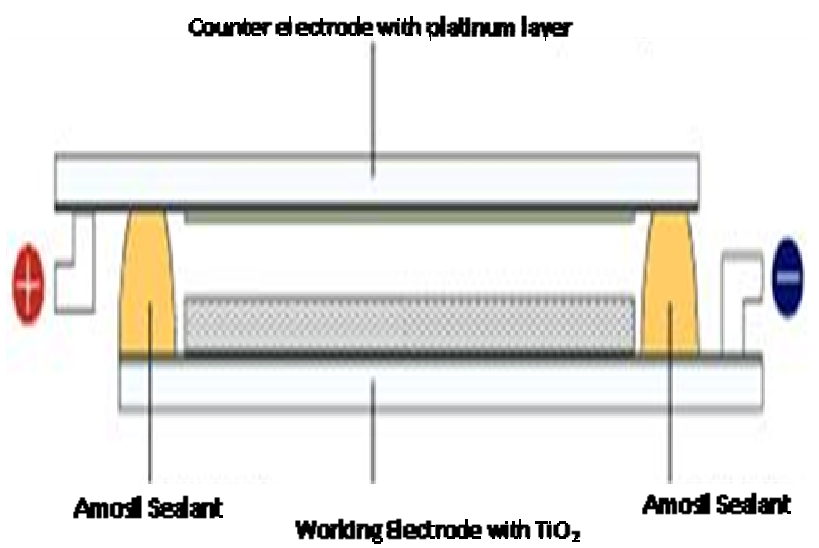

Figure 3. Cross-section of assembled dye solar cell showing sealing rim 


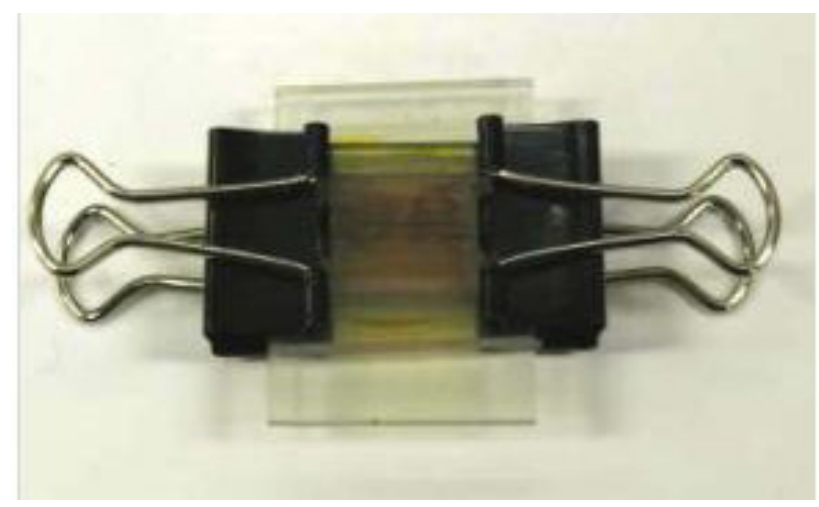

Figure 4. A typically assembled cell

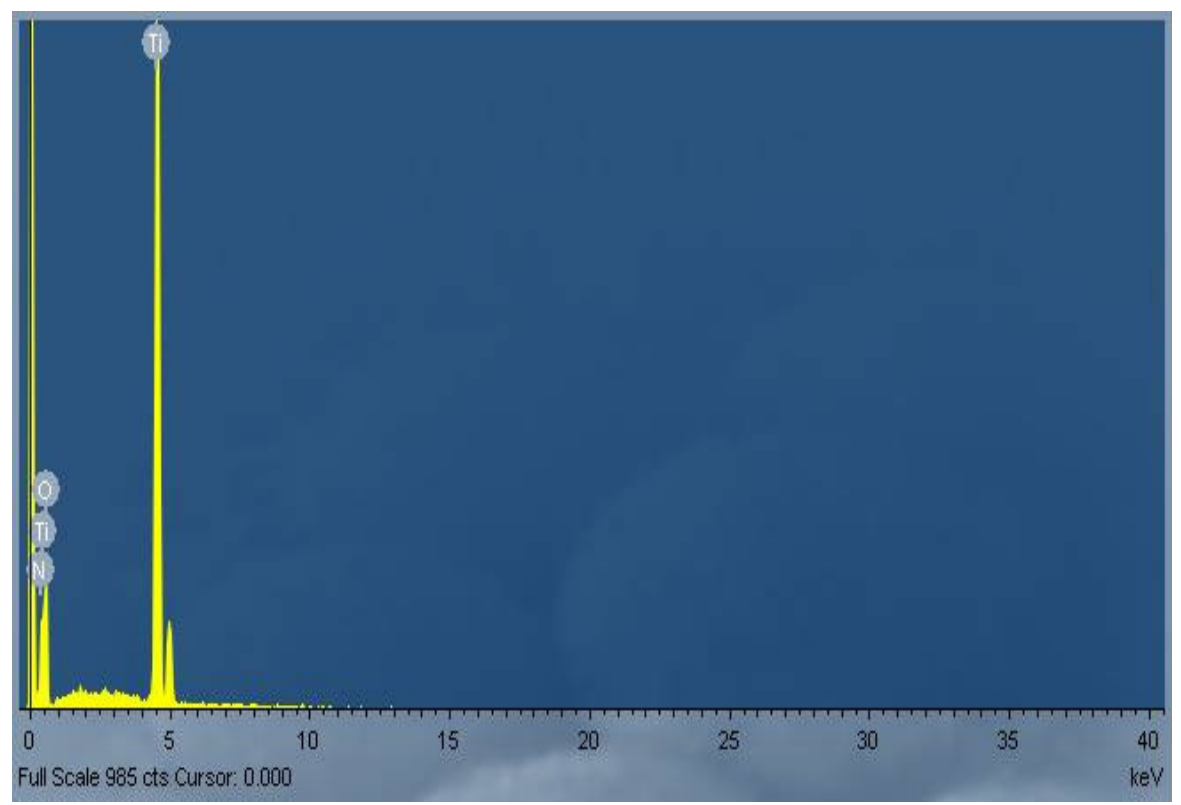

Figure 5. Result of the analysis of elemental composistion of $\mathrm{TiO}_{2}$ compound

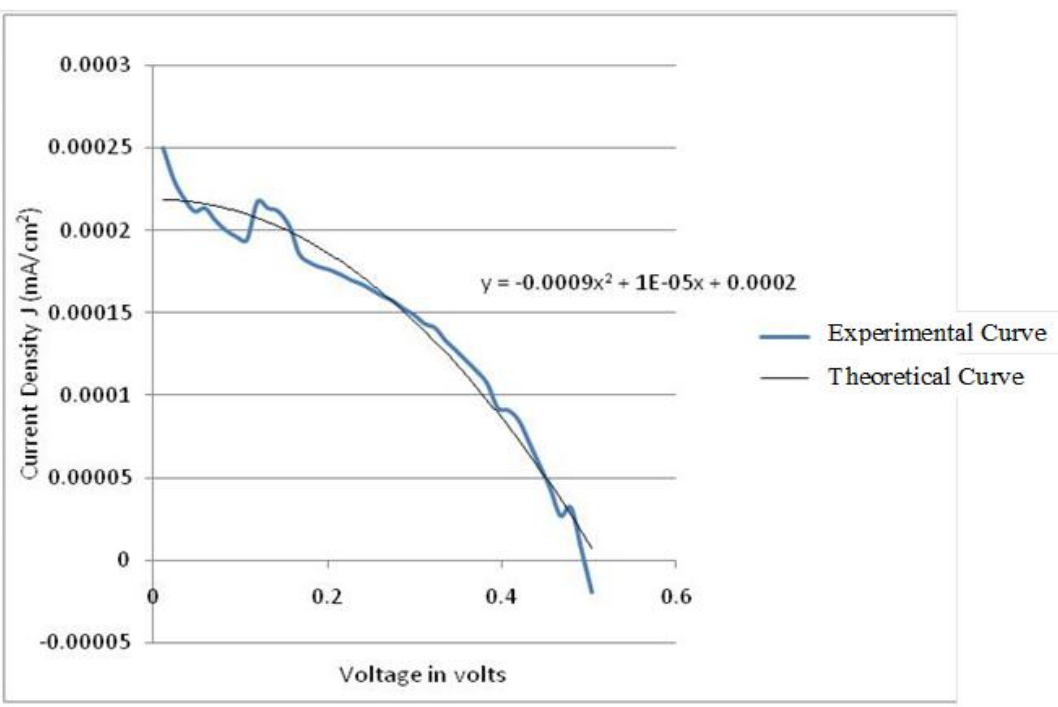

Figure 6. I-V Characteristics of the DSSC 